\title{
Systems Analysis as Infrastructural Knowledge
}

\author{
Scientific Expertise and Dissensus under State Socialism
}

Eglè Rindzevičiūtè

\begin{abstract}
This article explores the political effects of the development of systems analysis as a form of 'infrastructural knowledge' - that is as a form of knowledge concerned with infrastructure, and an infrastructure of knowledge - that contributed to internal dissensus among scientific experts in the Soviet Union. Systems expertise is largely missing from existing work on the history of Soviet infrastructure. The article presents a historical analysis of the development of governmental, managerial and industrial applications of systems analysis in the Soviet context, as well as the transfer of Soviet systems expertise to developing countries. It argues that systems analysis constitutes a form of infrastructural knowledge which enabled Soviet scientists to criticize governmental policies, particularly large-scale, top-down infrastructure projects. This critique is interpreted as an expression of a new normativity regarding what constitutes good governance; it became particularly salient when Soviet scientists were facing infrastructural projects in the global South. Systems analysis, in this way, constituted an important intellectual resource for endogenous liberalization of the authoritarian regime.
\end{abstract}

Keywords: systems analysis, infrastructure, governance, the Soviet Union, scientific expertise, dissensus

Dr Eglè Rindzevičiūtè is Associate Professor of Criminology and Sociology at Kingston University London, UK. She is the author of The Power of Systems: How Policy Sciences Opened Up the Cold War World (2016) and the editor of The Struggle for the Long-Term in Transnational Science and Politics: Forging the Future (2015), with Prof. Jenny Andersson. 
Dr Rindzevičiūtè has published articles in such journals as Modern Intellectual History, Slavic Review, The International Journal of Cultural Policy, Current Anthropology and Cahiers du monde Russe.

\section{Introduction}

This article considers the political effects of systems analysis as it was used to conceive, build and develop infrastructures in state socialist regimes between the 1960s and 1980s. Existing work on the political aspects of infrastructural projects describes the ways in which the failures of these projects have inspired civic movements leading to political change (Dawson 1996; Larkin 2013; Collier 2011; Szeman \& Boyer 2017). Furthermore, some scholars have proposed that controversies and conflicts surrounding infrastructure can be regarded as central to democracy because they question the status quo and empower marginal actors. For instance, in his influential study on the building of an oil pipe linking Azerbaijan, Georgia and Turkey, the political geographer Andrew Barry argued that this infrastructural project gave rise to new forms of political agencies, articulations and the pursuit of new interests and agendas, resulting in a "scientific" politics of dissensus. According to Barry, dissensus refers to the condition of disagreement and contestation that does not get resolved by presumably rational experts. Dissensus can become dormant and then re-activated in relation to new infrastructural projects. As technoscientific expertise perpetuates dissensus, the building of infrastructure, Barry suggests, has an important democratic value (Barry 2013, 9, 185).

Focusing on the Soviet case, this article seeks to expand the empirical perspective of these studies by introducing new types of actors and new types of conditions under which dissensus can emerge and flourish. First, developing the approach of Barry (2013), the Soviet case shifts the focus from infrastructural failure as a source of political action to the planning 
stage of infrastructure and its political effects. Second, of particular interest for this volume, rather than focus on party members, all-union and regional economic planners and local communities, who normally constitute the empirical focus of such work (Barry 2013; Obertreis 2017), this article discusses the role of systems analysis experts as producers of infrastructural knowledge. I argue that systems analysis experts were crucial for generating a politics of dissensus around infrastructural projects: they criticized the regime, articulating new notions of what good governance should look like. Systems analysis as a critical discourse on infrastructure was also facilitated by Cold War developmental politics, when the Soviet Union offered aid abroad in less developed countries, such as Cuba and Vietnam. It was in these contexts, when faced with infrastructural projects in developing countries, that the critical stance of systems analysts was particularly explicit.

The focus on the role played by Soviet systems experts in the planning of infrastructure helps to make a broader point of relevance for studies of the transformation of state socialist economies by pointing to the capacity of science and technology to contribute to endogenous change. Early studies of systems analysis in state socialist political economies characterized it as a primarily technocratic activity, where decisions were made on the basis of expert knowledge and decoupled from public participation and political debate. Indeed, scientific technocracy was politically legitimate as long as experts did not challenge publicly the decision-making power of the Communist Party of the Soviet Union (CPSU) and nomenclature officials (Obertreis 2017; Schönfelder forthcoming). However, recent work has brought back the idea that the transformation of state socialist regimes was also driven by forces that were endogenous to the governmental apparatus, such as officially sanctioned science and bureaucracy. As Yuen Yuen Ang suggested in relation to her study of China's economic transformation, “within authoritarian regimes, bureaucratic change is political change” (Ang 2016, 1128). The same applies to technoscientific expertise. The politics of 
systems analysis as dissensus that emerged around infrastructural questions is therefore different from dissidence, a form of outsider critique of Soviet government (Horvath 2005). Soviet systems dissenters were not "dissidents;" in fact, some of them did not approve of the dissident position at all.

"Infrastructure" was not a widely used term in the context of Soviet planning, where the Marxist term of the "material and technical base” were preferred. However, Soviet systems scholars used the term from at least 1979 (Gestwa 2014, 209-210; Emel'ianov 2006, 379). In line with Soviet political economy, they divided infrastructures into "productive" (rails, roads, water systems) and "non-productive” (education, public health) (Solius 1972). But this conceptual scheme excluded infrastructure built for the military-industrial complex. It also clashed conceptually with the Soviet doctrine of the scientific-technical revolution (STR), which, starting in 1956, posited that the state socialist regime was entering a postindustrial stage, where science and technology were direct drivers of social and economic change (Rindzevičiūtė 2016a, 27-33; Rindzevičiūtė 2018).

However, as the article shows, in practice, infrastructural projects interlinked science, state planning, and international politics. They placed systems scholars at the heart of some of the key political initiatives at home and abroad: conceiving, planning, building and maintaining infrastructure was not an isolated regional or national affair, but an internationally and transnationally networked activity. However, to appreciate the political impact of systems analysis as infrastructural knowledge one cannot use a "linear model”, according to which scientific expertise is just an input, a source of information for political decisions made by planning organs and the CPSU. In contrast, I argue that systems analysis should be regarded as a site where new governmental normativity was shaped and dissensus was practiced. These two components, I show, constituted an important resource for the democratization of an authoritarian regime. 


\section{Building Soviet infrastructure, creating dissensus}

According to Stephen Collier (2011, 49-64), the first attempt to go beyond the isolated public works that characterized Russian imperial modernization and to create infrastructure on a large scale could be found in the communist planning of the national electric grid, done at the State Commission for the Electrification of Russia (GOELRO). The GOELRO planners laid the conceptual foundations for the scientific forecasting of alternative scenarios of economic development and claimed that national planning required a new type of inter-sectorial knowledge to bridge different industry branches. After the Second World War, Soviet scientists used the intellectual legacy of GOELRO to legitimize the extension of "systems analysis” and operations research from military fields, such as logistics and the construction of advanced weapons systems, to civil planning. ${ }^{1}$

The very definition of systems analysis varied depending on the field of its application. But most Soviet official definitions of systems analysis emphasized its performative and pragmatic character: systems analysis "is a collection of methodological means that are used to prepare and motivate decisions in relation to complex problems of a military, social, economic, scientific and technical nature” (Iudin 1976). Systems analysis, thus conceived, addresses "the problems of organization and the functioning of complex objects” (Blauberg and Iudin 1976). The systems experts who feature in this study share backgrounds in mathematics and computer science, which they applied to model the

\footnotetext{
${ }^{1}$ For key studies in the history of systems analysis and systems thinking in East and West see Cocks (1980), Harrison (1985), Susiluoto (1982); Elichigiroity (1999); Hughes and Hughes (2000); Mindell (2004); Heyck (2015); Crook (2016); Rindzeviciute (2016a, 2018); Siskin (2016); Allan (2018).
} 
functioning of complex systems, such as the ecology, the climate, organizations, industrial zones, agricultural farms, factories, mining, transport infrastructures and managerial apparatus.

The shared mathematical background was not a coincidence: since the 1950s the practice of systems analysis was increasingly linked with computer modeling and, from the 1960s, computerization of industrial infrastructures, such as electricity, oil and gas, and chemical plants. ${ }^{2}$ Systems expertise in infrastructure was to make planning, management and production more "efficient” and contribute to economic growth: systems analysts augmented branch expertise with integrated assessments of the planned infrastructure and its environment, technical, economic, and social consequences. Here systems analysis served the Soviet government on two global axes: first, the Soviet economy was expected to benefit from East-West transfer of the most advanced technology and know-how. Second, Soviet systems experts promoted the Soviet model of development in North-South transfer. In all, systems analysis was recognized as a priority area for domestic development and international transfer in Soviet research policy. ${ }^{3}$

The institutional channels that enabled this transfer included the United Nations Economic Commission for Europe (UNECE, est. 1947), the Organization for Economic Cooperation and Development (OECD, est. 1961), the International Institute of Applied Systems Analysis (IIASA, est. 1972), the International Council of Scientific Unions’ Scientific Committee on Problems of the Environment (ICSU, est. 1969) and the United

\footnotetext{
${ }^{2}$ See the administrative nomenclature of the State Committee for Science and Technology (GKNT), Protocol (26 November 1970), the Archive of the Russian Academy of Sciences (ARAN), op.6m, d. 473, l.19. The archival sources that this article builds on are mainly internal reports, communication and minutes of meetings at the Gosplan, the GKNT, the Presidium of the Academy of Sciences and the All-Union Computer Centre of the Academy of Sciences in Moscow.

${ }^{3}$ I base this statement on a decree of the All-Union Academy of Sciences that set out research priority areas for 1976-1990. ARAN, f.2, op.6m, d.518, l.11.
} 
Nation's Man and the Biosphere (MAB, est. 1971). ${ }^{4}$ The leading Soviet systems scientists had both formal (IIASA, UN, ICSU, MAB) and informal (OECD, UNECE) relations with international organizations, which helped co-produce and exchange statistical data, but also shape critical agendas. ${ }^{5}$ After all, according to the official Soviet definition, infrastructure was a central site of political contestation in the West, where infrastructure was part of the capitalist arsenal for exploiting the working class (Solius 1972). However, in some cases this narrow Marxist interpretation was ignored by East-West scientists who eagerly used the systems approach to the planning of infrastructure to build bridges. IIASA, for instance, commissioned reports on complex infrastructures such as the Tennessee Valley Authority and Bratsk-Ilimsk territorial production complex in Irkutsk, the trans-Siberian Baikal-Amur Mainline (BAM) and Shinkansen railway, which were to be co-written by Soviet and Western scholars (Knop 1977, 1976; Morosov and Podvoiski 1977).

The key issues in the practice of systems analysis in the Soviet Union were pervasive secrecy, and therefore scarce and poor quality data. Fine-grained case analyses rarely found their way into the public domain. For instance, the flagship journal of the All-Union Systems Research Institute (VNIISI), Systems Research (Sistemnye issledovaniia), established in 1969, contained only general theoretical articles in the 1970s and 1980s. This is despite the fact that VNIISI scholars developed a great many applications for the industry in this period. Data and reports which were sourced through international channels were restricted to internal circulation in selected institutes of the Soviet Academy of Sciences. This lack of

\footnotetext{
${ }^{4}$ The Russian Archive of the Economy (RGAE), f. 99, op. 1, d. 890, 1.127-130; (Selcer 2018; Rindzeviciute 2016a; Andersson and Duhautois 2016). For the history of Soviet systems scientists in East-West international organization, see Gemelli (1998), Riska-Campbell (2011), Rindzeviciute (2016).

${ }^{5}$ For instance, so keen was the secretary of the UN Development Planning Committee to hear a talk on industrial planning in state socialist countries, that he would offer the economist and future director of Gosplan's Institute for Scientific Research into the Economy (NIEI), Vadim N. Kirichenko, not only a 1,000 USD fee, but also a grant to do preliminary research. “Materialy... (1966-1974),” RGAE, f. 99, op.1, d.904, l.125-126.
} 
transparency was noticed and criticized: for instance, an engineer at the Ministry of Water Management and the Academy of Science’s Computer Centre proposed that an internal newsletter of VNIISI was made publicly available to all scholars. ${ }^{6}$ Because of this concern with secrecy, such requests were overlooked and the entire field of Soviet systems research remained in the shadows, underexplored and underappreciated. However, these difficulties, which were endemic and typical of Soviet science, should not suggest that systems scientists were inconsequential in practice. As this section shows, the key systems scientists derived their authority and legitimacy from their material successes in designing infrastructures. As a rule, such successful implementation of systems expertise can be found not in large flagship projects, but in localized applications, in the incremental creation of a computer infrastructure for Soviet industries and enterprises. This should not be surprising, as STS scholars have long argued that large technical systems always emerge incrementally, rather than being imposed from above (Edwards et al 2007, Star 1999). This insight is particularly productive in the case of Soviet infrastructure projects, where the emphasis on centralist, top-down and large scale projects was part of public propaganda. In reality, even Soviet infrastructure emerged by piece-meal, accompanied by internal dissensus among scientific experts.

A good example of the incremental and localized assembling of infrastructure is the Viktor Glushkov's widely studied project of an all-union automated system (OGAS), which never came to fruition as a full system. Scholars have pointed out that the Soviet failure to construct a large scale, centralized and integrated digital infrastructure demonstrated the regime's inability to respond to the challenges of the advanced political economy based on information (Castells 1996; Castells and Kiselyova 1995). ${ }^{7}$ Both technical lag and internal

\footnotetext{
${ }^{6}$ F. Efremenko, “Otchet,” (June-August 1979), ARAN, f.1918, op.1, d.447, l.78.

${ }^{7}$ For instance, archival documents show that Soviet computer centers were not linked into a digital network in 1973. However, there were several international networks in operation from 1973: an experimental connection linked the IIASA and the Institute of Control Problems (IPU) in Moscow in 1974 and the IIASANET network connected West and East
} 
institutional competition hampered the project of the Soviet internet. ${ }^{8}$ However, computerized systems were incrementally introduced, forming an archipelago of automation, intertwined with other vital industrial infrastructures, which were also assembled incrementally. Consider, for instance, the famous oil pipeline called Friendship (Druzhba), built between 1959 and 1964, to supply crude oil to Western Europe from the Soviet Union, which was expected to lay the foundations for close East-West relations in technology transfer (Gestwa 2014, 221). The Soviet Union contracted the pipes and other strategic materials from Italy and the UK, despite the United States’ open and covert attempts to block the trade deals. Western loans helped too, and in the 1980s Soviet gas began to flow from the fields in Western Siberia to the West (Petrovic 2017, 12). The actual local implementation of the pipelines stemmed not so much from the central authorities, but largely resulted from the lobbying of different industry groups; local interests, rather than long-term forecasts, determined the success of the pipeline construction (Nekrasov 2017). Pipeline construction did not follow a pre-defined, top-down plan and, although OGAS failed as a national system, the Institute of Cybernetics founded by Glushkov provided automated management systems to some $80 \%$ of overall pipelines. ${ }^{9}$

The OGAS story is important because it shows, first, the strategic importance of computerization, but also, second, that the success of computerization was intertwined with the development of different types of infrastructure. As systems scholars mainly had backgrounds in applied mathematics and computer science, they served as important

European systems research institutions in the 1970s (Rindzeviciute 2016a, 119-120). ARAN, f. 2, op.1, d. 66, 1.27-35.

${ }^{8}$ See the vast literature detailing the many reasons, technical, political and social: Conyngham (1980), Cave (1980), Crowe and Goodman (1994), Castells (1996), Pospelov and Fet (1998), Gerovitch (2002), Rindzeviciute (2011), Tatarchenko (2013), Peters (2016), Leeds (2016), and Ericson, this volume.

${ }^{9}$ In addition to Buniak (2010), see the online resource on Glushkov's activities: http://ogas.kiev.ua/perspective/ystoryya-odnoj-fotografyy-569. 
mediators between computer technology and decision making in infrastructure design. For instance, VNIISI scientists created different applications for planning decisions in industry enterprises, such as the Moskvich automobile factory, a Belarusian machine factory and the nuclear power plant constructions by the Soiuzatomenergostroi (construction company engaged in nuclear energy projects). In the 1980s VNIISI was commissioned by the Navy to create a computerized diagnostic system, MEDIKS, to assist in detection of heart conditions and assess coma states. This system was adopted in several military hospitals (Emel'ianov 2006, p.74-75). VNIISI also modelled complex technological processes for the Severonikel factory in Monchegorsk and created a demographic modeling system, Mul'tidem, which was used by the State Committee for Statistics (Goskomstat). VNIISI systems scientists developed models for territorial and branch industry planning; perhaps one of the best known applications was a model for development and management of the Institute of Steel at the Kansk-Achinsk Fuel and Energy complex (KATEK) and for Minusinsk electrotechnical industrial complex (Emel’ianov 2006, pp. 44, 120, 137, 325). As Rutland (1993, 137-8) noted, KATEK’s construction and management continued to fail, partially because it was based on an innovative technological system and partially because of its administrative regional status, which made the complex a lower priority.

Systems scientists derived their prestige from their position as problem solvers in the priority areas. The founder of VNIISI, Dzhermen Gvishiani, was the son-in-law of Prime Minister Kosygin and deputy director of State Committee for Science and Technology (GKNT), but many other systems scientists were also well connected and used these connections to put their applications into practice. According to VNIISI's scientist Iurii Popkov, it was thanks to the architect and urban planner Aleksei Gutnov, their contact at the research institute of the General Plan of the Development of Moscow, that VNIISI were able to create an operational computer model to analyze and control an urban macrosystem. This 
project was supported by the deputy chairman of the State Committee for Construction (Gosstroi), Genadii Fomin, and the chairman of the Architectural Planning Commission of Moscow, Mikhail Posokhin. The political profile of the project was further enhanced by its links with the East-West research collaboration on urban systems and demography at IIASA (Emel'ianov 2006, p.105-106, 114). One of the outcomes of this work was a model of gravitational zones (zones that attract visits, e.g. factories or shopping areas) the location of which is determined by transport infrastructure. This model enabled the exploration of the probabilistic interaction of urban subsystems, such as the population, economic basis, housing and services, which allowed the detection of new forms of urban dynamics (Emel’ianov 2006, 114-5).

Although further research needs be done on the outcomes of these applications of systems expertise, it should be clear by now that Soviet systems scientists, based at the central research institutes, were well positioned to claim the limited authority and autonomy that they were awarded in exchange for their service to the regime (Graham 1987; Holloway 1999). Unlike members of the general public and dissidents, systems scientists could attack infrastructural proposals at their planning stage. Indeed, the history of late modern Soviet infrastructure contains quite a few examples of such practices of internal dissent, which originated from both central institutions in Moscow and individual republics. Internal scientific dissensus was often directed against the highly symbolic projects of infrastructure. For instance, in 1970s Lithuania scientists protested against the plan to build additional reactors at Ignalina nuclear power plant, a plant that at the moment of its construction was the most powerful in the world (Stsiapanau 2017). In the mid-1980s VNIISI produced a costbenefit analysis advising the government against heavy, expensive investments in the further development of Baikal-Amur Railway (BAM), one of the Soviet projects of the century that was draining the country’s economic resources. Although BAM was continued, construction 
of a new high speed railway connecting Moscow and Leningrad was not pursued because of Stanislav Shatalin's report that demonstrated the project's load on the already struggling economy (Emel’ianov 2006, 374). Perhaps the most widely known case of internal scientific dissent is the opposition to Stalin's plans to divert Siberian rivers to irrigate the central Asian steppe. The river diversion project was resisted by many Soviet scientists, including pedologists, economists and environmental computer modelers (Duke 2006; Obertreis 2017; Schönfelder forthcoming). The latter ones had a particularly significant tool to make their arguments persuasive (Majone 1989): the computer technology. Systems modelers at VNIISI and the Academy of Science's Computer Centre in Moscow could draw on their internationally recognized expertise in computer simulation of hydrological processes and ecological modeling of the complex biosphere. Although VNIISI and the Computer Centre were competitors, they joined the effort to oppose the river diversion project, demonstrating its catastrophic consequences for complex ecological systems. Both scientific insights and personal feelings mattered in this case: the Computer Centre's director Anatoliy Dorodnitsyn is said to have spontaneously reacted to the idea of the river diversion, pointing out that this would cause desertification in Ukraine, a country that he was particularly fond of (Dorodnitsyna, Evtushenko, Shevchenko 2015).

The ability of systems analysis as infrastructural knowledge to generate and host continuous dissensus inside the governmental and technocratic elites was probably best expressed in the nascent fields of environmental science and Earth system modeling. According to the patron of global modeling and the Computer Center's deputy director for research, Nikita Moiseev, computer models of the global and complex biosphere had to become an epistemological and material link between different academic fields, becoming a 
sociomaterial network able to bridge institutional divides. ${ }^{10}$ The Computer Center's scientists designed a global modeling system of this kind to study the geophysical, ecological and socioeconomic changes in the Earth system, particularly focusing on how it is influenced by "homo sapiens as a species on the Earth". ${ }^{11}$ This model was conceptually based on Vladimir Vernadskii's idea of an Earth system comprised of physical processes of energy exchange and inspired by Vladimir Kostitsyn's attempts to model the global biosphere mathematically (Vernadsky [1926]1998; Kostitzin 1935). The physical Earth model was enriched with a "human activity” block, a sub-system, based on macroeconomic models of demographic and production data (which was in great shortage). Even more complex was a separate model of the unknown human future, "the scientific-technical progress,” which required at least "a simple description of and access to statistical data” on future trends. ${ }^{12}$ The model was conceptually designed to capture global development as a complex problem, where interaction between "the man and the environment" was defined as a problem of stability to be explored through existing operations research techniques. To furnish this model with the necessary data, Computer Center scholars cooperated with many other institutes, such as VNIISI, the Central Economic Mathematical Institute (CEMI), meteorology and oceanology institutes in Leningrad, Novosibirsk and Vladivostok as well as others (Rindzevičiūtė 2016a).

The original intention of global computer modeling was to produce new fundamental knowledge on the global biosphere, which would help build regional models that could supply reliable information for decision-making in the management of large sectors, such as fisheries, agriculture and so on. Such scaled-down models would investigate the multiple

\footnotetext{
${ }^{10}$ Nikita Moiseev to N.N. Bogoliubov (18 July 1983), “Novye rezul’taty v modelirovanii global'nykh biogeotsenoticheskikh protsessov,” ARAN, f.1918, op.1, d.519, 1.129-190.

${ }^{11}$ Ibid, l.132.

12 Ibid, l.137-143.
} 
failures of infrastructures as the result of the potential conflict. ${ }^{13}$ In 1983 the global modelers produced a powerful dissensus creating a significant controversy in defense and foreign policy: the famous report on the environmental effects of nuclear war. ${ }^{14}$ By actively initiating a public information campaign, Soviet scientists hoped that the nuclear winter study would send a clear and convincing message about the complexity of the "catastrophe" of nuclear war to the military, described as "the most dangerous people” (in Russian, samyi opasnyi narod) by the nuclear physicist Pyotr Kapitsa. ${ }^{15}$

Soviet systems scientists’ dissensus did not result in clear-cut resolutions (Barry 2013, 19). It even failed where it succeeded: the territorial production complex Bratsk was one of the world's most polluted cities. The celebrated East-West gas and oil pipes leaked, damaging the environment and leading to severe accidents, such as a gas explosion damaging two passenger trains in the Ural region in 1989. Pollution emitted from the nickel factory in Monchegorsk, which was made more productive thanks to VNIISI's fundamental research into boiling liquids, was killing forests in the surrounding area (Gestwa 2014, 218-219; Bruno 2016). Systems experts’ dissensus could not become open criticism of the planning organs or CPSU, at least not until Mikhail Gorbachev announced glasnost' in 1986. Notably, one of Gorbachev's advisors was the famous “dissenter” Nikita Moiseev (Rindzevičiūtè 2018; Rindzevičiūte 2019). However, as the next section shows, Soviet systems analysts felt less constrained to criticize the norms and practices embedded in state socialist governmental apparatus when facing infrastructural failures abroad and not in their own country.

\footnotetext{
${ }^{13}$ Reports which included not only accounts of environmental and demographic damage, but also failures of public health systems, decline of production, particularly agriculture, were discussed at the presidium of the Academy of Sciences in February 1983. ARAN, f.2, op.1, d.844, l.14, 100-148.

${ }^{14}$ For studies of nuclear winter, see Badash (2009), Edwards (2012), Rindzeviciute (2016) and Rubinson (2016).

${ }^{15}$ ARAN, f.2, op.1, d.844, l. 147.
} 


\section{Soviet systems dissensus faces international development}

The Cold War politics of development opened up opportunities for Soviet systems analysts to practice dissensus in relation to the building of infrastructure. The Soviet aid programs, which were called "economic cooperation" in Russian, created a wide, interlocking net of actors, which included scientific experts, whose actions revolved around the construction of new, large infrastructural projects (Engerman 2017, 11). Soviet expertise in systems analysis constituted an important intellectual export that was intended to contribute to the development of infrastructure in "friendly countries". ${ }^{16}$ The GKNT received requests and reports from Soviet diplomats in developing countries requesting assistance with planning expertise. For instance, a Soviet diplomat to Senegal reported that the UN Economic Commission for Africa, the Institute of Economic Development and Planning, wished to cooperate with Gosplan regarding regional planning in Africa. ${ }^{17}$ The all-union Academy of Sciences dedicated a research unit for the Methods for Planning Developing Systems, which regularly dispatched Soviet scientists to developing countries. Providing scientific expertise for infrastructure was a high priority on Soviet aid projects (Kochetkova et al. 2017).

Ironically, while Soviet industrial plants emitted high levels of pollution and agricultural melioration schemes crushed fragile ecologies, Soviet aid for developing countries emphasized environmental protection (Perelet 1986). Robert Darst (2001) described this phenomenon as a cynical "greening” of Soviet foreign policy. However, some of these environmental efforts were initiated by Soviet systems scientists themselves as they looked to

\footnotetext{
${ }^{16}$ For examples of similar Western export of automation for the development in Chile and Mexico, see Medina (2011) and Polgovsky (2017). For more on Soviet aid see SanchezSibony (2014) and Iandolo (2012).

17 “Materialy...1966-1974,” RGAE, f. 99, op.1, d.899, l. 15.
} 
learn from their experience abroad. For example, the Computer Centre in Moscow developed regional models for exploitation of oil resources in Ethiopia and, in the late 1970s, for an agricultural economy in Iraq (Dorodnitsyna, Evtushenko, Shevchenko 2015, 339). The Iraq modelling exercise generated insights into water management that were later adapted for the Soviet context. ${ }^{18}$ The most striking, however, is that being in a position of a donor conferred on the already influential scientists a sense of high status, imbuing them with a sense of responsibility and a duty to voice criticism. This becomes quite clear when reading internal reports written by Soviet systems scientists sent to Cuba and Vietnam.

In October 1978, Vladimir R. Khachaturov, then the head of the research unit of evolutionary systems design at the Computer Center, and a rising star of computer-based design of oil and gas extraction systems, was sent to the Institute of Mathematics, Cybernetics and Computer Technology of the Cuban Academy of Sciences to train local scientists. Khachaturov, who spoke Spanish fluently, spent ten days giving workshops on the engineering of imitational modeling systems that could be used for optimal planning and particularly the siting of industries (Dorodnitsyna, Evtushenko, Shevchenko 2015, 193). This trip took place in the context of the agreement for Soviet-Cuban cooperation in science and technology, signed in 1960, which committed the Soviets to training of Cuban experts on the ground. The director of the Computer Center first visited the Academy of Sciences in Havana only in 1967. Increasingly intensive cooperation developed in the 1970s: in 1973 the Computer Centre and the Institute of Informatics and Computer Technology of the Cuban Academy of Sciences signed an institutional cooperation agreement (Dorodnitsyna, Evtushenko, Shevchenko 2015, 183, 185). As the Cuban government charged its Academy of Sciences' institutes with creating a complex plan for the development of the national

\footnotetext{
18 “Otchet Vycheslitelnogo Tsentra AN SSSR o vypolnenie plana tekhnonauchnogo sotrudnechestva” (1979), ARAN, f.1918, op.1, d.445, l.10.
} 
economy in 1977, Soviet experts also consulted Cubans on planning methodologies and assisted in the making of five-year plans for the national economy (Kochetkova et al 2017, 13, 15). More specifically, Soviet experts studied the planning of the new Cuban urban infrastructure, the siting of settlements and management of population migration flows and offered policy advice on the development. ${ }^{19}$

In their internal reports from Cuba, Soviet experts noted not only the lack of access to energy and challenges of terrain (Kochetkova et al 2017, 13-14), but also the gap between the governmental practices and what they saw as a proper modern governmental imagination, based on systems thinking. Material infrastructures that resulted from flawed governmental decisions were seen as visible symptoms of an under-developed scientific governance. For example, Khachaturov found his Cuban colleagues mathematically "literate” and "gifted," as well as technically equipped: the research institute that he visited had Edinaia series computers, based on IBM S/360, produced in Eastern Europe (Goodman 2003, 24). However, according to Khachaturov, Cuban scientists lacked experience of designing large infrastructural systems and had next to no knowledge of mathematical modeling. Even more perplexing for this Soviet expert was his observation that the Cubans did not even consider the possibility of solving national economic problems with the help of computer modeling. Trying to show the benefits of systems modeling, Khachaturov demonstrated his model of a more rational siting of roads in Isla de Pinos (renamed Isla de Juventud in 1978). On the island massive motorways were built to symbolize the technological progress of Cuban communism. A more compact road infrastructure, however, would have saved very valuable fertile soil and, in turn, increased the production of citrus fruit by $10 \%$. Khachaturov was desperate about the lack of Cuban interest in modeling the systemic effects of new

\footnotetext{
${ }^{19}$ For example, in 1972 the sociologist V. Chuprov from IKSI requested permission to travel to Cuba to explore the migration and youth problems emerging in relation to new settlements. ARAN, f.1977, op.1, d.72, l.7.
} 
infrastructures, particularly as he considered Cuba to be a "modelable” country: the economy was not complex yet, primarily based on agriculture, the size of the territory was quite small and the relevant research data was largely available. ${ }^{20}$ Back at home Soviet modelers did not enjoy such conveniences. It is not likely that Khachaturov's criticism was taken into consideration. According to Diaz-Briquets and Perez Lopez (2000, 5), Cuba “wasted” the Soviet assistance in both funding and expertise, overinvesting into large scale agricultural projects without any regard to environmental costs. Not all flagship plans, like a project to drain sea water between Isla de Pinos and the mainland creating more agricultural land (DiazBriquets and Perez Lopez 2000, 15) were implemented. Yet former colonial elites of Cuba mourned the modernization of the island where "big, ugly buildings and people, people everywhere” replaced what was remembered as idyllic, pre-industrial beauty (Neagle 2016, 276).

The extensive report by Khachaturov testifies to a strong professional take on what constitutes proper systems analysis. His frustration with his peers in Cuba reveals a strong normativity and expectation that similar standards should be applied in the Soviet Union as well. Other Soviet systems scientists were also explicit about the existing gap between the theory and reality of infrastructural planning, both at home and in the developing countries. Particularly telling here is Moiseev's report from his one month-long visit to Vietnam by the invitation of the local state committee for science and technology in the winter of 1978-1979, almost immediately after the conclusion of Soviet-Vietnamese treaty of friendship and cooperation (Radchenko 2014, 127). The trajectory of modern Vietnam’s development was shaped by French colonial infrastructure-building, but, beginning in 1954, Northern Vietnam

\footnotetext{
20 “Othcet o nauchnoi komandirovki sotrudnika Vych. tsentra AN SSSR zavedushego sektorom metodov proektirovaniia razvivaiushchikh sistem kandidat fiziko-matematicheskikh nauk V.R. Khachaturova v Institut matematiki, kibernetiki i vycheslitelnoi tekhniki AN Kuby” (15 December 1978), ARAN, f. 1918, op.1, d.423, l.76-94.
} 
received aid with education and infrastructural projects from the Soviet Union, as well as Warsaw pact countries (Prybyla 1966; Sanchez-Sibony 2015). While, for example, East German engineers constructed the town of Vinh to showcase the state socialist standards of residential housing, Soviet experts like Moiseev were consulted by the Vietnamese government leaders on planning methodologies (Schwenken 2015). ${ }^{21}$ Many Vietnamese scientists were trained in Soviet institutes in Moscow and Leningrad. Ho Chi Minh himself visited the Computer Center in Moscow commenting that it was "very interesting, but difficult to understand” how computerized systems research could be applied in a country at a very low level of development (Dorodnitsyna, Evtushenko, Shevchenko 2015, 128). The Computer Center would establish a lasting cooperation with the nascent Vietnamese computer science. Indeed, even a building at the research center in Hanoi would be designed by Nikolai Kupriianov, who also designed building of the Moscow’s Computer Center (Dorodnitsyna, Evtushenko, Shevchenko 2015, 90).

A cooperation agreement between the Soviet GKNT and the Vietnam State Committee of Science and Technology was signed in 1959; in 1960 a Vietnamese delegation, headed by the vice minister of defense, visited the Computer Center in Moscow, and, in 1974, Dorodnitsyn travelled to renew the agreement. From the second half of the 1970s the Computer Center's directors and scientists paid regular annual visits to North and South Vietnam, particularly Hanoi, where scientific research was concentrated, but also the sea biology laboratory in Haiphong, as well as to Ho Chi Minh City and the Dalat nuclear research institute. The Vietnamese weather forecasts were done on Minsk-22 and Minsk-32 computers. As Deng Xiaoping’s China was increasingly opening up channels of cooperation

\footnotetext{
${ }^{21}$ Dorodnitsyn, who, alongside with Moiseev, co-directed the Computer Centre, headed the Soviet delegation to establish scientific-technical cooperation with Vietnam in JanuaryFebruary 1971. During this trip Dorodnitsyn was shown Vinh as a site of the US destruction, which laid in ruins "overgrown with the jungle” ((Dorodnitsyna, Evtushenko, Shevchenko 2015, 203).
} 
with Western powers, the Soviet Union had increased its aid to Vietnam to secure the Soviet position in the region (Radchenko 2014, 13-14). From the 1980s, Soviet scientists sought to establish cooperation with the Vietnamese in areas that required urgent environmental attention, such as the Mekong delta and the underwater shelf, the investigation of which was important for the construction of oil rigs (Dorodnitsyna, Evtushenko, Shevchenko 2015, 1845, 204-205, 207, 441).

During his stay Moiseev read lectures on systems analysis, particularly imitation modelling and dialogue systems; these technologies were designed to align computational processes with the organizational need to work on different projects, continually adding new data. Moiseev's audience included members of the Vietnamese state planning committee, the state security university, as well as academic researchers, many of whom received their training in the Soviet Union. Just like Khachaturov in Cuba, Moiseev agreed that local scholars had good scientific potential, but he could not help noticing the scars of the Vietnam wars: in his report Moiseev wrote that only about $30 \%$ of scholars stayed, while the rest emigrated. Vietnamese academia was divided by the class struggle: some of older generation scholars had to be "re-educated" in the spirit of communist ideology (in Russian, perevospitaniye). As Moiseev raised the issue of the lack of scientists, a vice-chairman of the Vietnamese Gosplan dismissed his comment saying that "they used to receive 1,000 USD before liberation. They are certainly all spies. Let them grow rice!” Moiseev described Saigon’s situation as “catastrophic," "hanging like a stone around the neck of the country." Vietnamese leaders, he wrote, should find “organizational forms” to use the competence of the existing Saigon inhabitants. ${ }^{22}$ Moiseev expressed his disappointment with the absence of the systemic organization of research, lack of leadership and "fragmented themes" in the

\footnotetext{
${ }^{22}$ I refer to place names as they appear in the sources, e.g. Peking, Saigon and so on. "Otchet o nauchnoi komandirovke vo V'etnam zam. direktora Vych. tsentra chlena korrespondenta AN SSSR Moiseeva N.N.,” ARAN, f.1918, op.1, d.423, l. 129-130.
} 
university curriculum. ${ }^{23}$ One can sense an indirect criticism of the universalist ambitions of Soviet planning in Moiseev's account of his meeting with the head of the planning methodology of the Vietnamese Gosplan, who was intended to copy “blindly” the Soviet system of planning, without considering the importance of local context, particularly the wartime experience, which, according to Moiseev, formed the foundation for Soviet scientific governance.

In this report Moiseev effectively argued that governmental and planning projects must be organically rooted in the local context and not mechanically imposed from above. He was particularly concerned about the Vietnamese colleague's authoritarian views and reliance on direct command methods. The attitude in the Vietnamese Gosplan, wrote Moiseev, could be summarized in the following sentence: "if people are sufficiently disciplined and trained to implement orders, do you really need all that science of governance?”. ${ }^{24}$ This, for Moiseev, was a lamentable approach to governance.

The Russian scientist also expressed his dissatisfaction with what he described as the Vietnamese obsession with giant scale. As he put it, when the Vietnamese experts try to model a process of production, they start with a model based on many millions of tons. Similarly, when an agricultural cooperative is organized, the planners talk about their ambition to develop thousands of hectares into productive fields. In this process, wrote Moiseev, Vietnamese experts had not only forgotten their national traditions, but also the absence of mundane but necessary infrastructure, such as roads, machine equipment and transport. Even basic agricultural science, which requires that a rice field would not be larger than "100 m2", is ignored.

\footnotetext{
${ }^{23}$ Ibid, l.127.

${ }^{24}$ Ibid.
} 
Moiseev contrasted this obsession with grand scale with "pragmatism," which he valued highly. According to Moiseev, without pragmatism any governance degrades into mechanical compliance (in Russian, nachetnichestvo). In Vietnam he claimed to have found signs of pragmatism only at the Central Committee’s Institute of Management, directed by a European-trained economist. Other than that, Moiseev found it unjustifiable that Saigon promoted the prestigious high-tech areas of science, such as space and plasma research, at the expense of basic, mundane systems engineering that would improve people's everyday lives. ${ }^{25}$ Moiseev was not alone in voicing this criticism: many Soviet but also East European, experts criticized Asian developing countries for their obsession with Stalinist megaprojects (Szalontai 2008; Radchenko 2014).

There is more to what can appear as donor-client critique. Moiseev, by criticizing Vietnam, practiced a politics of dissensus: he expressed a new governmental normativity, which did not blindly support the priority of big science and the military-industrial complex. This new normativity later found expression in Gorbachev’s reforms: indeed, Gorbachev himself compared his experience of reforming the state socialist system with that of the Vietnamese in 1989; although later, according to Radchenko, Gorbachev bitterly regretted that the Vietnamese appeared to be overtaking what was earlier posited as a development model, the Soviet Union (Radchenko 2014, 135).

What is even more important, this example shows that critical dissensus was formed not only in contact with the liberal capitalist model, which was held up as an example for Soviet modernization, but also in contact with the non-Western developmental experience in the global South. Contacts between Eastern experts, as Gewirtz (2017) recently demonstrated, were much more regular and significant than Cold war and development historians have

25 Ibid, 1.127-131. 
tended to think: East-East learning was an integral part of the liberalization of state socialist political economies.

\section{Conclusion}

Modern states used infrastructural projects to enchant or revolutionize their populations (Szeman \& Boyer 2017; Boyer 2016; Larkin 2013; Anand, Gupta, Apppel 2018), while failing infrastructures enabled populations to question the governing regimes (Gestwa 2014; Schwenkel 2015). When infrastructure fails, it becomes visible (Edwards 2004; Edwards et al 2007; Lampland and Star 2009; Graham 2010; Harvey and Knox 2015). And indeed, Soviet efforts to construct new infrastructures, both material and epistemological, often failed or were implemented at great human cost (Kotkin 1995; Josephson 2002; Bruno 2016).

However, this article argues that infrastructural projects had the potential to transform governing regimes not only at their end points of use or failure, but also at their planning stages. This becomes quite clear when attention is shifted away from planners or managers (who tend to be criticized and held responsible when infrastructure fails) to systems analysis experts (who remain invisible in the public eye). This article proposed that Soviet systems analysts, by commenting on large infrastructure projects, engaged in a politics of dissensus, as they continuously revealed the failures of infrastructural planning. This critical position was made possible by the authority that these analysts gained though having made significant contributions to the military-industrial complex: their loyalty was not under question and they enjoyed high social status and relative professional autonomy (Holloway 1999).

In this context, I argued, systems analysis played the role of infrastructural knowledge, bounding theoretical insights and methodologies with organization- and institution-building efforts, materialities and social worlds. When this infrastructure-building 
effort took Soviet systems scholars to developing countries, systems analysis facilitated their criticisms of what were considered to be typical practices of state socialist, centrally commanded economic systems. Systems analysis as infrastructural knowledge harbored a normative view on governability, seeking to transform the political imaginaries of governance by underscoring the importance of local context and dangers of "large science and technology” (Jasanoff and Kim 2015). In line with Ang’s work on Chinese bureaucracy (Ang 2016, 14441), this insight must be extended to recognize the importance of internal deliberation in what might appear as a monolithic Soviet technocracy.

It is therefore fundamentally important to draw on the existing theoretical basis of the politics of infrastructure in order to better understand the role of technoscientific expertise in the Soviet Union. As is demonstrated in this special issue, state socialist political economy developed through highly contested negotiations between science, political ideology and pragmatic actors. What should not get lost in this conversation is that this was not only a struggle for power, but also a search for answers to the question of what could be done to lift populations out of poverty. In many cases this search failed and, where Soviet modernization succeeded, growth was achieved at a high human and environmental cost. ${ }^{26}$ Yet a general lesson can be learned from this Soviet story: intellectual, political and social histories should address systems analysis as infrastructural knowledge that can give rise to a politics of dissensus, providing new categories for imagination and enterprise with the possibility for change.

\section{Acknowledgments}

${ }^{26}$ For struggles in the postwar rebuilding of city infrastructure see Dale (2015). 
I want to thank Andrew Barry, Ivan Boldyrev, Adam Leeds, Francis Dodsworth, Till Düppe, Timm Schönfelder, and two anonymous reviewers for their generous and constructive comments on the earlier versions of the article. Views and errors are mine only.

\section{References}

Anand, Nikhil, and Akhil Gupta, Hannah Apppel, eds. 2018. The Promise of Infrastructure. Durham and London: Duke University Press.

Andersson, Jenny, Sibylle Duhautois. 2016. "Futures of Mankind: The Emergence of the Global Future,” 106-125. In Rens Van Munster and Sylvest Casper, eds. The Politics of Globality since 1945: Assembling the Planet. London: Routledge.

Ang, Yuen Yuen. 2016. How China Escaped the Poverty Trap. Ithaca: Cornell University Press.

Barry, Andrew. 2013. Material Politics: Disputes Along the Pipeline. Oxford: WileyBlackwell.

Blauberg, I.V. and E.G. Iudin. 1976. “Sistemnyi podkhod.” Bol'shaia Sovetskaia entsiklopediia, volume 23. Third edition. Moscow: Sovetskaia entsiklopediia.

Bockman, Johanna and Michael Bernstein. 2008. "Scientific Community in a Divided World: Economists, Planning, and Research Priority during the Cold War.” Comparative Studies in Society and History 50 3: 581-613.

Boyer, Dominic. 2016. “Revolutionary Infrastructure,” 174-186. In Penny Harvey, Casper Bruun, and Atsuro Morita, eds., Infrastructures and Social Complexity: A Companion. London: Routledge, 2017.

Bruno, Andy. 2016. The Nature of Soviet Power. Cambridge: The University of Cambridge Press. 
Cave, Martin. 1980. Computers and Economic Planning: The Soviet Experience. Cambridge: The University of Cambridge Press.

Castells, Manuel. 1996. The Information Age: Economy, Society and Culture. Cambridge, MA: Blackwell.

Castells, Manuel and Emma Kiselyova. 1995. The Collapse of Soviet Communism: A View from the Information Society.

Cocks, Paul. 1980. "Rethinking the Organizational Weapon: The Soviet System in a Systems Age.” World Politics 32 2: 228-257.

Collier, Stephen. 2011. Post-Soviet Social: Neoliberalism, Social Modernity, Biopolitics. Princeton: Princeton University Press.

Conyngham, William. 1980. “Technology and Decision Making: Some Aspects of the Development of OGAS.” Slavic Review 39 3: 426-445.

Crook, Tom. 2016. Governing Systems: Modernity and the Making of Public Health in England, 1830-1910. Berkeley: University of California Press.

Crowe, Gregory D. and Seymour E. Goodman. 1994. "S.A. Lebedev and the Birth of Soviet Computing,” Annals of the History of Computing IEEE 16, 1: 4-24.

Dale, Robert. 2015. “Divided We Stand: Social Unity and Post-War Reconstruction in Soviet Russia, 1945-1953.” Contemporary European History 24, 4: 493-516.

Darst, Robert G. 2001. Smokestack Diplomacy: Cooperation and Conflict in East-West Environmental Politics. Cambridge, MA: MIT Press.

Dawson, Jane. 1996. Eco-Nationalism: Anti-Nuclear Activism and National Identity in Russia, Lithuania and Ukraine. Durham, NC and London: Duke University Press.

Diaz-Briquets, Sergio and Jorge Perez Lopez. 2000. Conquering Nature: The Environmental Legacy of Socialism in Cuba. Pittsburgh: The University of Pittsburgh Press. 
Dobrov, Genadii and Renat Perelet. 1986. NTR i prirodookhrannaia politika. Kiev: Naukovaia dumka.

Dorodnitsyna, V.V., Iu.G.Evtushenko, V.V.Shevchenko. 2015. A.A.Dorodnitsyn: Zhizn’ kak vremia derznovennoe ( $k$ 105-letiiu so dnia rozhdeniia). Moscow: VTsRAN.

Duke, D. 2006. "Seizing Favours from Nature: The Rise and Fall of Siberian River Diversion,” 3-34. In T. Tvedt and E. Jakobsson, eds., A History of Water, vol.1. Water Control and River Biographies. London: I.B.Tauris.

Edwards, Paul. 2004. "Infrastructure and Modernity: Force, Time, and Social Organization in the History of Sociotechnical Systems.” In Thomas Misa et al., ed. Modernity and Technology. Cambridge, MA: The MIT Press.

Edwards, Paul, and S. Jackson, Geoff Bowker, C. Knobel. 2007. Understanding Infrastructure: Dynamics, Tensions and Design. Ann Arbour: Deep Blue. Edwards, Paul. 2012. “Entangled histories: Climate Science and Nuclear Weapons Research.” Bulletin of the Atomic Scientists 68, 4: 28 - 40.

Elichirigoity, Fernando. 1999. Planet Management: Limits to Growth, Computer Simulation, and the Emergence of Global Spaces. Evanston: Northwestern University Press.

Elie, Marc. 2013. “Late Soviet Responses to Disasters, 1989-1991: A New Approach to Crisis Management or the Acme of Soviet Technocratic Thinking?” Soviet and Post-Soviet Review 40, 2:214-238

Emel'ianov, Stanislav, ed. 2006. 30 let institute sistemnogo amaliza Rosiiskoi akademii nauk: istoriia sozdaniia i razvitiia Instituta sistemnogo analiza, 1976-2006 gg. Moscow: KomKniga. Engermann, David. 2017. “Development Politics and the Cold War.” Diplomatic History 41, $1: 1-19$. 
Harrison, Mark. 1985. Soviet Planning in Peace and War, 1938-1945. Cambridge:

Cambridge University Press.

Harvey, Penny and Hannah Knox. 2015. Roads: And Anthropology of Infrastructure and Expertise. Ithaca: Cornell University Press.

Horvath, Robert. 2005. The Legacy of Soviet Dissent: Dissidents, Democratisation and Radical Nationalism in Russia. London and New York: Routledge.

Hughes, Agatha and Thomas Hughes, eds. 2000. Systems, Experts, and Computers: The Systems Approach in Management and Engineering, World War II and After. Cambridge, MA: MIT Press.

Gemelli, Giuliana, ed., 1998. The Ford Foundation and Management Education in Western and Eastern Europe (1950s-1970s). Brussels: European Interuniversity Press.

Gerovitch, Slava. 2002. From Newspeak to Cyberspeak: A History of Soviet Cybernetics. Cambridge, MA: The MIT Press.

Gestwa, Klaus. 2014. “The Expansion of Infrastructures as ‘The Second Party Programme’: A Look at the Bright and Dark Sides of Soviet Life,” 209-228. In Martin Schiefelbusch and Hans-Ludger Dienel, eds. Linking Networks: The Formation of Common Standards and Visions for Infrastructure Development. Farnham: Ashgate.

Gewirtz, Julian. 2017. Unlikely Partners: Chinese Reformers, Western Economists, and the Making of Global China. Cambridge, MA: Harvard University Press.

Goodman, Seymoor. 2003. “The Origins of Digital Computing in Europe: Retracing Paths of Influential, But Often Isolated, Pioneers.” Communications of the ACM 46, 9: 21-25.

Graham, Loren. 1987. Science, Philosophy, and Human Behavior in the Soviet Union. New York: Columbia University Press.

Graham, Stephen. 2010. Disrupted Cities: When Infrastructure Fails. London: Routledge. 
Heyck, Hunter. 2015. Age of System: Understanding the Development of Modern Social Science. Baltimore: John Hopkins University Press.

Holloway, David. 1999. "Physics, the State and Civil Society in the Soviet Union.” Historical Studies in the Physical and Biological Sciences 30, 1: 173-192.

Hughes, Thomas and Agathe C. Hughes, eds. 2000. Systems, Experts, and Computers: The Systems Approach in Management and Engineering, World War II and After. Cambridge, MA: The MIT Press.

Humphrey, Caroline. 2005. “Ideology and Infrastructure.” Journal of Royal Anthropological Institute 11: 39-58.

Iandolo, Alessandro. 2012. “The Rise and Fall of the 'Soviet Model of Development' in West Africa, 1957-64.” Cold War History 12, 4: 703-704.

Iudin, B.G. 1976. "Sistemnyi analiz.” Bol’shaia Sovetskaia entsiklopediia, volume 23. Third edition. Moscow: Sovetskaia entsiklopediia.

Jasanoff, Sheila and Sang-Hyun Kim, eds. 2015. Dreamscapes of Modernity: Sociotechnical Imaginaries and the Fabrication of Power. Chicago and London: The University of Chicago Press.

Josephson, Paul R. 2002. Industrialized Nature: Brute Force Technology and the Transformation of the Natural World. Washington D.C.: Island Press.

Kline, Ronald. 2015. The Cybernetics Moment, Or Why We Call Our Age the Information Age. Baltimore: John Hopkins University Press.

Knop, H. 1976. The Tennessee Valley Authority Experience. IIASA Collaborative Paper. IIASA, Laxenburg, Austria: CP-76-002.

Knop, H. 1977. The Bratsk-Ilimsk Territorial Production Complex. Proceedings of the 2nd IIASA Conference on Case Studies of Large-Scale Planning Projects, March 1976. IIASA Collaborative Paper. IIASA, Laxenburg, Austria: CP-77-003. 
Kochetkova, Elena, and David Damtar, Lilia Boliachevets, Polina Slyusarchuk, Julia Lajus. 2017. "Soviet Technological Projects and Technological Aid in Africa and Cuba, 1960s1980s.” Working Paper BRP 143/HUM/2017, National Research University - Higher School of Economics, Moscow, 1-16.

Kornai, Janos. 1992. The Socialist System: The Political Economy of Communism. Princeton: Princeton University Press.

Kostitzin, Vladimir. 1935. Evolution de l'atmosphère : circulation organique, époques glaciaires. Paris: Hermann.

Kotkin, Stephen. 1995. Magnetic Mountain: Stalinism as a Civilization. Berkeley: The University of California Press.

Lampland, Martha and Susan Leigh Star. 2009. Standards and Their Stories: How Quantifying, Classifying, and Formalizing Practices Shape Everyday Life. Ithaca: Cornell University Press.

Larkin, Brian. 2013. “The Politics and Poetics of Infrastructure.” Annual Review of Anthropology 42: 327-343.

Leeds, Adam. 2016. “Dreams in Cybernetic Fugue: Cold War Technoscience, the Intelligentsia, and the Birth of Soviet Mathematical Economics.” Historical Studies in the Natural Sciences 46 5: 633-68.

Majone, Giandomenico. 1989. Evidence, Argument and Persuasion in the Policy Process. New Haven: Yale University Press.

Medina, Eden. 2011. Cybernetic Revolutionaries: Technology and Politics in Allende's Chile. Cambridge, MA: The MIT Press.

Mindell, David. 2004. Between Human and Machine: Feedback, Control and Computing Before Cybernetics. Baltimore: Johns Hopkins University Press. 
Morosov, Y. and G. Podvoiski. 1977. The Shinkansen and Baikal-Amur Railways (BAM): A Comparison of Large-Scale Program Management Experience. IIASA Working Paper.

IIASA, Laxenburg, Austria: WP-77-012.

Nekrasov, Viacheslav. 2017. "Decision-Making in the Soviet Energy Sector in Post-Stalinist Times: The Failure of Khrushchev’s Economic Modernization Strategy,” 165-200. In

Petrovic, Jerom, ed. 2017. Cold War Energy: A Transnational History of Soviet Oil and Gas. Cham: Palgrave Macmillan/Springer.

Neagle, Michael. 2016. America's Forgotten Colony: Cuba's Isle of Pines. Cambridge: The University of Cambridge Press.

Obertreis, Julia. 2017. Imperial Desert Dreams. Cotton Growing and Irrigation in Central Asia, 1860-1991. Göttingen: V\&R Unipress.

Perelet, Renat. 1986. “CMEA Countries Cooperate with Developing Nations to Protect Environment.” Ambio 15, 4:250-251.

Perovic, Jeronim, ed. 2017. Cold War Energy: A Transnational History of Soviet Oil and Gas. Cham: Springer/Palgrave Macmillan.

Peters, Benjamin. 2016. How Not to Network A Nation. Cambridge, MA: The MIT Press. Petrovic, Jerom, ed. 2017. Cold War Energy: A Transnational History of Soviet Oil and Gas. Cham: Palgrave Macmillan/Springer.

Polgovsky, Mara. 2017. “The Cybernetic State and the Search for a Non-Human Government in Latin America: Socialist and Neoliberal Visions, Experiences, Failures and Returns”. An unpublished paper, presented at the conference The Afterlives of Cybernetics, CRASSH, the University of Cambridge, November.

Pospelov, D. A. and Ia.I.Fet, eds. 1998. Ocherki istorii informatiki v Rossii. Novosibirsk: Nauchno-izdatel'skii tsentr OIGGM SO RAN. 
Prybyla, Jan. 1966. “Soviet and Chinese Economic Aid to North Vietnam.” The China Quaterly 27: 84-100.

Radchenko, Sergei. 2014. Unwanted Visionaries: The Soviet Failure in Asia at the End of the Cold War. Oxford: Oxford University Press.

Rindzevičiūtè, Eglè. 2008. Constructing Soviet Cultural Policy: Cybernetics and Governance in Lithuania After World War II. Linköping: Linköping University Press.

Rindzevičiūtè, Eglè. 2011. “Internal Transfer of Cybernetics and Informality in the Soviet Union: The Case of Lithuania, 119-137.” In Sari Autio-Sarasmo and Katalin Miklossy, eds. Reassessing Cold War Europe. London \& New York: Routledge.

Rindzevičiūtè, Eglè. 2016. “A Struggle for the Soviet Future: The Birth of Scientific Forecasting in the Soviet Union.” Slavic Review 75, 1: 52-76.

Rindzevičiūtè, Eglè. 2016a. The Power of Systems: How Policy Sciences Opened Up the Cold War World. Ithaca: Cornell University Press.

Rindzevičiūtè, Eglè. 2018. "Soviet Policy Sciences and Earth System Governmentality.” Modern Intellectual History FirstView: 1-30.

Rindzevičiūtè, Eglè. 2019. “The Unlikely Revolutionaries: Decision Sciences in the Soviet Government,” 217-249. In Daniel Bessner and Nicolas Guilhot, eds. The Decisionist Imagination: Sovereignty, Social Science and Democracy in the 20th Century. Oxford: Berghahn Books.

Riska-Campbell, Leena. 2011. Bridging East and West: The Establishment of the International Institute for Applied Systems Analysis (IIASA) in the United States Foreign Policy of Bridge Building, 1964-1972. Helsinki: The Finnish Society of Science and Letters. Rutland, Peter. 1993. The Politics of Economic Stagnation in the Soviet Union: The Role of Local Party Organs in Economic Management. Cambridge: Cambridge University Press. 
Sanchez-Sibony, Oscar. 2014. Red Globalization: The Political Economy of the Soviet Cold War from Stalin to Khrushchev. Cambridge: Cambridge University Press.

Schiffer, Jonathan. 1989. Soviet Regional Economic Policy: The East-West Debate over Pacific Siberian Development. London: Macmillan.

Schönfelder, Timm. Forthcoming. "Slaves to the Yiel: Scientific Bonanza and IrrigationMegalomania in the Kuban River Basin.” In Eike Christian Heine and Martin Meiske, eds., Scientific Bonanzas: Infrastructures as Places of Knowledge Production. Pittsburgh: The University of Pittsburgh Press.

Schwenkel, Christina. 2015. "Spectacular Infrastructure and its Breakdown in Socialist Vietnam.” American Ethnologist 42, 3: 520-534

Selcer, Perrin. 2018. The Postwar Origins of the Global Environment: How the United Nations Built Spaceship Earth. New York: Columbia University Press.

Siskin, Clifford. 2016. System. Cambridge: The MIT Press.

Solius, G.P. 1972. “Infrastruktura.” Bol'shaia Sovetskaia entsiklopediia, volume 10. Third edition. Moscow: Sovetskaia entsiklopediia.

Star, Susan. 1999. “The Ethnography of Infrastructure.” American Behavioral Scientist 43, 3: 377-391.

Stsiapanau, Andrei. 2017. Lithuania: Short Country Report. HONEST: History of Nuclear Energy and Society, WP2.

Susiluoto, Ilmari. 1982. The Origins and Development of Systems Thinking in the Soviet Union Political and Philosophical Controversies From Bogdanov and Bukharin to PresentDay Re-Evaluations. Helsinki: Suomalainen Tiedeakatemia.

Szalontai, Balasz. 2008. “The Diplomacy of the Economic Reform in Vietnam: The Genesis of Doi Moi, 1986-1989.” Journal of Asiatic Studies 51, 2: 199-252. 
Szeman, Imre and Dominique Boyer, eds. 2017. Energy Humanities: An Anthology.

Baltimore: John Hopkins University Press.

Tatarchenko, Ksenia. 2013. ““A House with a Window to the West”: The Akademgorodok Computer Center (1958-1993).” PhD diss., Princeton University.

Vernadsky, Vladimir. 1998/1926. The Biosphere. Berlin: Springer. 